\title{
ВПЛИВ ТРАНСКРАНІАЛЬНОӤ МІКРОПОЛЯРИЗАЦІЇ НА МОЗКОВУ ГЕМОДИНАМІКУ У ПАЦІЄНТІВ З ПЕРИНАТАЛЬНОЮ ГІПОКСІЙНО-ІШЕМІЧНОЮ ЕНЦЕФАЛОПАТІЕЮ
}

\author{
ОК. В. Яценко \\ Інститут фізіології імені О. О. Богомольця Національної академії наук України, Київ \\ «Неврологічна клініка доктора Яченко», м. Київ, Україна
}

РЕЗЮМЕ. Перинатальна гіпоксійно-ішемічна енцефалопатія (ПГІЕ) - актуальна проблема неврології та неонатології. Перспективним для лікування ПГІЕ $\epsilon$ неінвазивний інструмент моделювання активності головного мозку - транскраніальна мікрополяризація.

Мета - дослідити можливість застосування методу мікрополяризації в комплексному лікуванні пацієнтів 3 перинатальною гіпоксійно-ішемічною енцефалопатією.

Матеріали та методи. У ході дослідження на базі «Неврологічної клініки доктора Яценко» (м. Київ) було обстежено і комплексно проліковано 45 дітей у віці від 2 до 12 років з гіпоксійно-ішемічною енцефалопатією. До групи порівняння, яким проводили базисні лікувально-реабілітаційні заходи, увійшли 15 дітей, до основної - 30, яким на фоні базисної терапії додатково проводили курс мікрополяризації. Транскраніальну мікрополяризацію (ТМП) виконували згідно з розробленими індивідуальними схемами лікування залежно від локалізації патології. Мозкову гемодинаміку дітей з ПГІЕ до і після комплексного лікування з застосуванням методу ТМП аналізували за допомогою транскраніальної доплерографії судин голови.

Результати. ТМП зменшувала коефіцієнт асиметрії кровообігу по середніх мозкових артеріях (СМА) на $12,7 \%$, тоді як у групі порівняння лише на 4,4 \%; по передніх мозкових артеріях (ПМА) - на 9,5 \%, а у групі порівняння цей показник становив 1,1%. ТМП вірогідно зменшувала високі середні швидкості кровообігу за цикл (СШК) по базилярній артерії (БА), СМА та ПМА (на 22,0 \%, 17,7 \% та 7,5 \% відповідно); у групі порівняння вірогідної позитивної динаміки відзначено не було. ТМП вірогідно збільшувала низькі СШК по БА, СМА та ПМА (на 28,4 \%, 21,9 \% та 10,4 \% відповідно); статистично вірогідне зростання СШК на 10,1 \% було лише по СМА у пацієнтів групи порівняння.

Висновки. Отримані дані свідчать про те, що комплексна терапія з використанням транскраніальної мікрополяризації у пацієнтів з ПГІЕ покращує показники мозкової гемодинаміки, а також позитивно впливає на клінічний перебіг захворювання.

КлючОВІ СлОВА: мікрополяризація; перинатальна гіпоксійно-ішемічна енцефалопатія; транскраніальна доплерографія.

Вступ. Гіпоксійно-ішемічне ураження головного мозку - найчастіший патологічний стан, який діагностують у неонатальному періоді [1]. За даними різних авторів, частота цієї патології становить 2-3 випадки на 1000 доношених новонароджених у розвинених країнах і до 26 випадків на 1000 новонароджених - у слаборозвинених країнах [2]. Перинатальна гіпоксійно-ішемічна енцефалопатія (ПГІЕ) обумовлена недостатнім надходженням кисню до тканин головного мозку, яке пов'язане як зі зниженням вмісту кисню в артеріальній крові, так і зі зменшенням мозкового кровообігу $[1,3]$. Особливості васкуляризації головного мозку дитини у ранньому неонатальному періоді, підвищена вразливість капілярів, залежність кровообігу головного мозку від стабільності системної гемодинаміки - всі ці фактори сприяють порушенню мозкового кровообігу і розвитку гіпоксійно-ішемічної енцефалопатії [4]. Недостатнє надходження кисню до тканин головного мозку призводить до каскаду патологічних процесів в ішемізованій тканині мозку: глютамат-кальцієвої ексайтотоксичності, запалення і оксидативного стресу $[5,6]$. Такі несприятливі події в мозку новонародженого впливають на подальший розвиток дитини і призводять до дов- готривалих тяжких неврологічних дефектів, таких як розумова недостатність, труднощі в навчанні, рухові розлади тощо [2].

Досі недостатньо досліджені шляхи запобігання або зменшення пошкоджень при перинатальній гіпоксійно-ішемічній енцефалопатії і тривають пошуки ефективних терапевтичних засобів лікування ПГІЕ [7]. Тому особливий інтерес для лікування ПГІЕ викликає перспективний неінвазивний інструмент моделювання активності мозку - транскраніальна мікрополяризація (ТМП).

Мікрополяризація - це різновид нейромодуляції, яка дозволяє змінювати функціональний стан різних ділянок ЦНС під дією малого постійного струму (до 1 мА), який можна порівняти з біопотенціалів нейронів, що дозволяє застосовувати цей метод навіть у дітей [8]. Було показано, що ТМП, завдяки прямому впливу на нейрони, які знаходяться у піделектродному просторі, модулює синаптичну передачу шляхом регулювання нейромедіаторів, таких як ГАМК, глутамат, серотонін, дофамін та інших [9]. Однією з унікальних особливостей мозкового кровообігу $\epsilon$ тісний структурний і функціональний контакт між кровоносними судинами, нейронами та гліальними клі- 
Огляди літератури, оригінальні дослідження, погляд на проблему, ювілеї

тинами. Hawkins i Davis запропонували концепцію нейроваскулярної одиниці, яка складається з ендотеліальних клітин, клітин мозку і позаклітинного матриксу та функціонує як єдине ціле за допомогою біохімічного сигналінгу [10]. Нейромедіатори, що вивільняються з активних нейронів, викликають збільшення $\mathrm{Ca}^{2+}$ в астроцитах, що спричиняє вивільнення вазоактивних метаболітів арахідонової кислоти з астроцитарних ніжок, які знаходяться на кровоносних судинах $[10,11]$. Синтез простагландину E2 і епоксіейкозатрієнової кислоти розширює кровоносні судини, в той час як 20-гідроксіейкозатетраєнова кислота звужує судини. Вивільнення $\mathrm{K}^{+} 3$ астроцитних ніжок також може сприяти вазодилатації [12].

3 огляду на тісний взаємозв'язок між активністю нейронів і мозковим кровообігом, очікується, що ТМП може впливати на гемодинаміку, збільшуючи перфузію мозку, як показано в дослідженнях на тваринах [13] і людях [14].

Мета - дослідити можливість застосування методу мікрополяризації в комплексному лікуванні пацієнтів з перинатальною гіпоксійно-ішемічною енцефалопатією.

Матеріал і методи дослідження. Робота виконана на базі "Неврологічної клініки доктора Яценко" (м. Київ). У ході дослідження було обстежено та комплексно проліковано 45 дітей віком від 2 до 12 років з перинатальною гіпоксійно-ішемічною енцефалопатією. Оскільки показники мозкової гемодинаміки варіюють залежно від віку дитини, то під час транскраніальної доплерографії враховували показники фізіологічної норми мозкового кровотоку, характерні для певного віку. Дітей було поділено на дві рандомізовані за основними параметрами (стать і вік) групи. До першої (порівняльної) групи, яким проводили базисні лікувально-реабілітаційні заходи, увійшли 15 дітей, до другої (основної) групи - 30 дітей, яким на фоні базисної терапії додатково проводили курс транскраніальної мікрополяризації (ТМП).

Базисна терапія містила традиційний комплекс лікувально-реабілітаційних заходів, які комбінували залежно від індивідуальних потреб пацієнта. Перед початком курсу лікування дітей проводили клінічне обстеження: збір скарг за загальноприйнятою методикою, вивчення анамнезу, соматоневрологічне обстеження, інструментально-функціональну діагностику (електроенцефалографія, електронейроміографія). Комплексне обстеження дітей також проводили суміжні спеціалісти (логопед, психолог-дефектолог, реабілітолог тощо) за загальноприйнятими методиками.

Транскраніальну мікрополяризацію виконували за допомогою сертифікованого апарата для мікрополяризації «Реамед-Полярис» (Санкт-Пе- тербург, Росія). Електроди розташовували на шкірі голови, згідно з розробленими індивідуальними схемами лікування, залежно від локалізації патології. Курс лікування складався з 10 щоденних 40-хвилинних сеансів.

Метод транскраніальної доплерографії (ТДГ) судин головного мозку використовували для дослідження мозкової гемодинаміки дітей з ПГІЕ до та після комплексного лікування з застосуванням транскраніальної мікрополяризації. ТДГ - це неінвазивний, нешкідливий, високоінформативний та доступний метод ультразвукового дослідження судин головного мозку, що дозволяє оцінити швидкість кровообігу в інтракраніальних судинах для виявлення гемодинамічно значущих змін. Доплерографічне дослідження проводили в положенні лежачи (голова - по середній лінії) у стані спокою на аналізаторі «Ангіодин» («БИОСС», Росія) за стандартною методикою з використанням імпульсного режиму і транскраніального зонда 3 частотою випромінювання 2 Мгц.

Підлягали локації магістральні судини голови: середня (СМА), передня (ПМА) мозкові артерії та базилярна артерія (БА). Для оцінки мозкової гемодинаміки та стану кровообігу в магістральних артеріях голови у дітей аналізували максимальну систолічну швидкість кровообігу, кінцеву діастолічну швидкість, середню швидкість кровообігу за цикл (СШК) та коефіцієнт асиметрії (KA), який розраховували за формулою: KA=((V2-V1)/V1)×100\%, де V1 i V2 - середня швидкість кровообігу в парних артеріях.

Підтвердження терапевтичної ефективності комплексного методу лікування здійснювалося методом варіаційної статистики. Порівняння середніх значень досліджуваних показників здійснювали за допомогою t-критерію Стьюдента при нормальному розподілі показників. Відповідність закону нормального розподілу ознак перевіряли з використанням критерію Шапіро-Уїлка. Дані наведені у вигляді середнього арифметичного (М) та стандартної похибки вибірки (m). Статистично значущими вважали відмінності за умов $\mathrm{P}<0,05$.

Результати й обговорення. Для оцінки терапевтичної ефективності транскраніальної мікрополяризації аналізували клінічні дані, отримані до та після завершення терапії. Згідно з даними первинного комплексного клініко-нейрофізіологічного обстеження, в обох групах дітей із ПГІЕ було виявлено функціональні та органічні розлади стану ЦНС. Результати транскраніальної доплерографії судин голови дітей із ПГІЕ обох груп спостереження свідчили про ті або інші порушення мозкового кровообігу в магістральних артеріях голови: гемодинамічно значима (більше 15 \%) асиметрія кровообігу по СМА і ПМА; високі швид- 
Огляди літератури, оригінальні дослідження, погляд на проблему, ювілеї кості кровообігу по БА, СМА і ПМА; низькі швидкості кровообігу по БА, СМА і ПМА та інші.

Дані проведеного ТДГ-обстеження показали, що діти з ДЦП обох груп під впливом проведеної терапії у більшості випадків мали сприятливі зміни мозкової гемодинаміки. Позитивні зміни мозкового кровообігу спостерігали у 82 \% пацієнтів основної групи і у $56 \%$ осіб групи порівняння.
Для об'єктивної оцінки рівня порушень мозкової гемодинаміки в магістральних артеріях голови до і після комплексного лікування дітей з перинатальною гіпоксійно-ішемічною енцефалопатією застосовували коефіцієнт асиметрії (КА) кровообігу по СМА і ПМА. Результати аналізу цих показників ТДГ дітей з ПГІЕ обох груп представлені в таблиці 1.

Таблиця 1. Результати аналізу даних транскраніальної доплерографії (коефіцієнт асиметрії кровообігу по СМА і ПМА) дітей обох груп спостереження до і після лікування

\begin{tabular}{|l|c|c|c|c|}
\hline \multirow{2}{*}{\multicolumn{1}{|c|}{ Група }} & \multicolumn{2}{|c|}{ КА кровообігу по СМА, \% } & \multicolumn{2}{c|}{ КА кровообігу по ПМА, \% } \\
\cline { 2 - 5 } & до лікування & після лікування & до лікування & після лікування \\
\hline Порівняльна, $\mathrm{n}=15$ & 15,8 & 11,4 & 12,3 & 11,2 \\
\hline$\Delta, \%$ & \multicolumn{2}{|c|}{4,4} & 1,1 & 6,7 \\
\hline Основна, $\mathrm{n}=30$ & 17,9 & 5,2 & \multicolumn{2}{|c|}{9,5} \\
\hline$\Delta, \%$ & \multicolumn{2}{|c|}{12,7} \\
\hline
\end{tabular}

У дітей основної групи після лікування із використанням ТМП відзначали зменшення КА кровообігу по СМА до 5,2 \% (до лікування цей показник становив 17,9 \%). Позитивну динаміку також спостерігали і в пацієнтів групи порівняння, але КА кровообігу по СМА зменшився недостовірно тільки до 11,4 \% (початкове значення - 15,8 \%) (див. табл. 1).

Така ж позитивна динаміка щодо коефіцієнта асиметрії кровообігу по передній мозковій арте- рії була зафіксована у дітей з ПГІЕ, яким проводили ТМП. У них спостерігали зменшення КА кровообігу по ПМА на 9,5 \%, тоді як у групі порівняння цей показник становив лише 1,1% (див. табл. 1).

Стан мозкової гемодинаміки залежить від віку дитини, тому для оцінки змін показника середньої швидкості кровообігу по БА, СМА, ПМА враховували нормативні дані для різних вікових груп. Показники СШК по БА, СМА і ПМА, залежно від патерну ТДГ, представлені в таблиці 2.

Таблиця 2. Середня швидкість кровообігу в дітей із ПГІЕ обох груп спостереження під впливом лікування

\begin{tabular}{|c|c|c|c|c|}
\hline \multirow{2}{*}{ Патерн ТДГ, М \pm} & \multicolumn{2}{|c|}{ Група порівняння, n=15 } & \multicolumn{2}{|c|}{ Основна група, $\mathrm{n}=30$} \\
\hline & до лікування & після лікування & до лікування & після лікування \\
\hline $\begin{array}{l}\text { Високі швидкості кровообігу: } \\
\text { - по БА }\end{array}$ & $66,1 \pm$ & $63,0 \pm$ & $66,7 \pm$ & $52,0 \pm$ \\
\hline$\Delta, \%$ & \multicolumn{2}{|c|}{$-4,7$} & \multicolumn{2}{|c|}{$-22,0$} \\
\hline - по CMA & $96,8 \pm$ & $91,7 \pm$ & $97,4 \pm$ & $80,2 \pm$ \\
\hline$\Delta, \%$ & \multicolumn{2}{|c|}{$-5,3$} & \multicolumn{2}{|c|}{$-17,7$} \\
\hline - по ПМА & $64,7 \pm$ & $63,4 \pm$ & $65,6 \pm$ & $60,7 \pm$ \\
\hline$\Delta, \%$ & \multicolumn{2}{|c|}{$-2,0$} & \multicolumn{2}{|c|}{$-7,5$} \\
\hline $\begin{array}{l}\text { Низькі швидкості кровообігу: } \\
\text { - по БА }\end{array}$ & $40,7 \pm$ & $43,2 \pm$ & $39,4 \pm$ & $55,0 \pm$ \\
\hline$\Delta, \%$ & \multicolumn{2}{|c|}{$+5,8$} & \multicolumn{2}{|c|}{$+28,4$} \\
\hline - по CMA & $55,4 \pm$ & $61,6 \pm$ & $56,3 \pm$ & $72,1 \pm$ \\
\hline$\Delta, \%$ & \multicolumn{2}{|c|}{$+10,1$} & \multicolumn{2}{|c|}{$+21,9$} \\
\hline - по ПМА & $51,7 \pm$ & $54,6 \pm$ & $52,7 \pm$ & $58,8 \pm$ \\
\hline$\Delta, \%$ & \multicolumn{2}{|c|}{$+5,3$} & \multicolumn{2}{|c|}{$+10,4$} \\
\hline
\end{tabular}

Примітки. 1. * - статистично вірогідні відмінності $(\mathrm{P}<0,05)$.

2. n- кількість досліджених осіб у групі.

Висока швидкість кровообігу по БА в дітей основної групи, які проходили комплексне лікування із застосуванням транскраніальної мікрополяризації, статистично достовірно зменшилася на 22,0\%. У цій групі дітей також відзначено статистично достовірне зменшення високих швидкостей кровообігу по СМА і ПМА (на 17,7 \% і 7,5 \% відповідно). Позитивну динаміку цього параметра спостерігали і в пацієнтів групи порівняння, але вона не була статистично достовірною.

Після проведення курсу ТМП відзначали статистично достовірне зростання низьких швидкостей кровообігу по БА, СМА і ПМА $(28,4 \%, 21,9 \%$, 10,4 \% відповідно) у пацієнтів основної групи. 
Огляди літератури, оригінальні дослідження, погляд на проблему, ювілеї

Також відзначали позитивну динаміку цих патернів ТДГ і в дітей групи порівняння, але статистично достовірно зросла швидкість кровообігу тільки по СМА (10,1\%).

Позитивна динаміка патернів транскраніальної доплерографії у дітей з перинатальною гіпоксійно-ішемічною енцефалопатією під впливом лікування відображалася в компенсації мозкового кровообігу, зникненні вазоспазмів різного ступеня, нормалізації тонусу магістральних судин голови, зменшенні коефіцієнта асиметрії кровообігу по середніх та передніх мозкових артеріях. Після проведення комплексного лікування з застосуванням транскраніальної мікрополяризації відзначено статистично достовірне зменшення середніх високих і збільшення середніх низьких лінійних швидкостей кровообігу по БА, СМА і ПМА.

Зміни показників транскраніальної доплерографії на тлі лікування можуть бути наслідком нормалізації мозкового кровообігу, збільшення капіляризації, активації обох відділів вегетативної нервової системи (з переважанням впливу на симпатичний відділ) $[15,16]$.

Результати транскраніальної доплерографії судин голови дітей з гіпоксійно-ішемічною енцефалопатією, яким проводили комплексне ліку- вання із застосуванням транскраніальної мікрополяризації, показали, що позитивна динаміка патернів ТДГ у них була достовірно вищою, ніж у групі порівняння. Дані проведеного ТДГ-обстеження свідчать про більшу терапевтичну ефективність комплексного методу з використанням ТМП у лікуванні дітей з ПГІЕ, порівняно з традиційними лікувально-реабілітаційними заходами.

Висновки. Застосування транскраніальної мікрополяризації в комплексному лікуванні пацієнтів з перинатальною гіпоксійно-ішемічною енцефалопатією забезпечує позитивну динаміку показників транскраніальної доплерографії судин голови у 82 \% пацієнтів основної групи, на відміну від 56 \% у групі порівняння. Отримані дані свідчать про те, що комплексна терапія з використанням транскраніальної мікрополяризації у пацієнтів з ПГІЕ покращує показники мозкової гемодинаміки, а також позитивно впливає на клінічний перебіг захворювання.

Перспективи подальших досліджень. Планується дослідження впливу комплексного лікування з використанням транскраніальної мікрополяризації на електроенцефалографічні показники у пацієнтів з перинатальною гіпоксійно-ішемічною енцефалопатією.

\section{ЛІТЕРАТУРА}

1. Perinatal brain injury: From pathogenesis to neuroprotection / J. J. Volpe // Ment. Retard. Dev. Disabil. Res. Rev. - 2001. - Vol. 7. - P. 56-64.

2. Hypoxic-ischemic encephalopathy: A review for the clinician / M. Douglas-Escobar, M. D. Weiss // JAMA Pediatr. 2015. - Vol. 169. - P. 397-403.

3. Neonatal seizures in hypoxic-ischaemic encephalopathy-risks and benefits of anticonvulsant therapy / J. Shetty // Dev. Med. Child. Neurol. - 2015. - Vol. 57. - P. 40-43.

4. Pathophysiology of perinatal hypoxic-ischemic encephalopathy-biomarkers, animal models and treatment perspectives / V. Riljak, J. Kraf, A. Daryanani [et al.] // J. Physiol. Res. - 2016. - Vol. 65 (Supplementum 5). - P. S533-S545.

5. Neuronal cell death in neonatal hypoxia-ischemia / F. J. Northington, R. Chavez-Valdez, L. J. Martin // Ann. Neurol. - 2011. - Vol. 69. - P. 743-758.

6. Oxidative stress and endoplasmic reticulum (ER) stress in the development of neonatal hypoxic-ischaemic brain injury / C. Thornton, A.A. Baburamani, A. Kichev [et al.] // Biochem. Soc. Trans. - 2017. - Vol. 45 (5). - P. 1067-1076

7. Mitochondria, bioenergetics and excitotoxicity: New therapeutic targets in perinatal brain injury / B. Leaw, S. Nair, R. Lim [et al.] // Front. Cell Neurosci. - 201. - Vol. 11. - P. 199.

8. Effect of transcranial direct current stimulation over the primary motor cortex on cerebral blood flow: a time course study using near-infrared spectroscopy / H. Takai, A. Tsubaki, K. Sugawara [et al.]//Adv. Exp. Med.Biol.-2016.Vol. 876. - P. 335-341.
9. Transcranial direct current stimulation: State of the art 2008 / M. A. Nitsche, L. G. Cohen, E. M. Wassermann [et al.] // Brain Stimul. - 2008. - Vol. 1. - P. 206-223.

10. The blood-brain barrier/neurovascular unit in health and disease / B. T. Hawkins, T. P. Davis // Pharmacol. Rev. - 2005. - Vol. 57. - P. 173-185.

11. Binaural blood flow control by astrocytes: listening to synapses and the vasculature / A. J. Mishra // J. Physiol. 2017. - Vol. 595. - P. 1885-1902.

12. Glial and neuronal control of brain blood flow / D. Attwell, A. M. Buchan, S. Charpak [et al.]//Nature.-2010.Vol. 468. - P. 232-43.

13. Hemodynamic responses in rat brain during transcranial direct current stimulation: a functional near-infrared spectroscopy study / C. H. Han, H. Song, Y. G. Kang [et al.] // Biomed. Optics Express. - 2014. - Vol. 13. - P. 1812-1821.

14. Effects of transcranial direct current stimulation (tDCS) on human regional cerebral blood flow / X. Zheng, D. C. Alsop, G. Schlaug // Neuroimage. - 2011. - Vol. 58. P. 26-33.

15. Concurrent measurement of cerebral hemodynamics and electroencephalography during transcranial direct current stimulation / M. Giovannella, D. Ibañez, C. GregoriPla [et al.] // Neurophotonics. - 2018. - Vol. 5(1) . - P. 015001.

16. Pelletier S. J. Cellular and molecular mechanisms of action of transcranial direct current stimulation: evidence from in vitro and in vivo models / S. J. Pelletier, F. Cicchetti // Int. J. Neuropsychopharmacol. - 2014. - Vol. 18 (2) . - P. 1-13. 
Огляди літератури, оригінальні дослідження, погляд на проблему, ювілеї REFERENCES

1. Volpe, J.J. (2001). Perinatal brain injury: From pathogenesis to neuroprotection. Mental Retardation and Developmental Disabilities Research Reviews, 7 (1), 56-64.

2. Douglas-Escobar, M., \& Weiss, M.D. (2015). Hypoxic-ischemic encephalopathy: A review for the clinician. JAMA Pediatrics, 169, 397-403. doi: 10.1001/jamapediatrics.2014.3269.

3. Shetty, J. (2015). Neonatal seizures in hypoxicischaemic encephalopathy-risks and benefits of anticonvulsant therapy. Developmental Medicine and Child Neurology, 57, 40-43. doi: 10.1111/dmcn.12724.

4. Riljak, V., Kraf, J., Daryanani, A., Jiruška, P., \& Otáhal, J. (2016). Pathophysiology of perinatal hypoxic-ischemic encephalopathy - biomarkers, animal models and treatment perspectives. Physiological Research, 65 (Supplementum 5), S533-S545.

5. Northington, F.J., Chavez-Valdez, R., \& Martin, L.J. (2011). Neuronal cell death in neonatal hypoxia-ischemia. Annals of Neurology, 69, 743-758. doi: 10.1002/ana.22419.

6. Thornton, C., Baburamani, A.A., Kichev, A., \& Hagberg, H. (2017). Oxidative stress and endoplasmic reticulum (ER) stress in the development of neonatal hypoxicischaemic brain injury. Biochemical Society Transactions, 45 (5), 1067-1076. doi: 10.1042/BST20170017.

7. Leaw, B., Nair, S., Lim, R., Thornton, C., Mallard, C., \& Hagberg, H. (2017). Mitochondria, bioenergetics and excitotoxicity: new therapeutic targets in perinatal brain injury. Frontiers in Cell Neuroscience, 11, 199. doi: 10.3389/Fncel.2017.00199.

8. Takai, H., Tsubaki, A., Sugawara K., Miyaguchi S. Oyanagi K., Matsumoto T., ... Yamamoto N. (2016). Effect of transcranial direct current stimulation over the primary motor cortex on cerebral blood flow: a time course study using near-infrared spectroscopy. Advances in Experimental Medicine and Biology, 876, 335-341. doi: 10.1007/9781-4939-3023-4_42.
9. Nitsche, M.A., Cohen, L.G., Wassermann, E.M., Priori, A., Lang, N., Antal, A., ... Pascual-Leone, A. (2008). Transcranial direct current stimulation: State of the art 2008. Brain Stimulation, 1, 206-223. doi: 10.1016/j. brs.2008.06.004

10. Hawkins, B.T. \& Davis, T.P. (2005). The blood-brain barrier/neurovascular unit in health and disease. Pharmacological Reviews, 57, 173-185.

11. Mishra, A.J. (2017). Binaural blood flow control by astrocytes: listening to synapses and the vasculature. The Journal of Physiology, 595 (6), 1885-1902. doi: 10.1113/ JP270979.

12. Attwell, D., Buchan, A.M., Charpak, S., Lauritzen, M., Macvicar, B.A., Newman, E.A. (2010). Glial and neuronal control of brain blood flow. Nature, 468, 232-243. doi: 10.1038/nature09613.

13. Han, C.H., Song, H., Kang, Y.G., Kim, B.M., \& Im, C.H. (2014). Hemodynamic responses in rat brain during transcranial direct current stimulation: a functional near-infrared spectroscopy study. Biomedical Optics Express, 5 (6), 1812 1821. doi: 10.1364/BOE.5.001812.

14. Zheng, X., Alsop, D.C., Schlaug, G. (2011). Effects of transcranial direct current stimulation (tDCS) on human regional cerebral blood flow. Neuroimage, 58 (1), 26-33. doi: 10.1016/j.neuroimage.2011.06.018.

15. Giovannella, M., Ibañez, D., Gregori-Pla, C., Kacprzak, M., Mitjà, G., Ruffini, G., \& Durduran, T. (2018). Concurrent measurement of cerebral hemodynamics and electroencephalography during transcranial direct current stimulation. Neurophotonics, 5 (1), 015001. doi: 10.1117/1. NPh.5.1.015001.

16. Pelletier, S.J, Cicchetti, F. (2014). Cellular and molecular mechanisms of action of transcranial direct current stimulation: evidence from in vitro and in vivo models. The International Journal of Neuropsychopharmacology, 18 (2), 1-13. doi: 10.1093/ijnp/pyu047.

\title{
ВЛИЯНИЕ ТРАНСКРАНИАЛЬНОЙ МИКРОПОЛЯРИЗАЦИИ НА МОЗГОВУЮ ГЕМОДИНАМИКУ У ПАЦИЕНТОВ С ПЕРИНАТАЛЬНОЙ ГИПОКСИЧЕСКИ-ИШЕМИЧЕСКОЙ ЭНЦЕФАЛОПАТИЕЙ
}

ОЕ. В. Яценко

\author{
Институт физиологии им. А. А. Богомольца НАН Украины, Киев \\ "Неврологическая клиника доктора Яченко», г. Киев, Украина
}

РЕЗЮМЕ. Перинатальная гипоксически-ишемическая энцефалопатия (ПГИЕ) - актуальная проблема неврологии и неонатологии. Перспективным для лечения ПГИЕ является неинвазивный инструмент моделирования активности головного мозга - транскраниальная микрополяризация.

Цель - исследовать возможность применения метода микрополяризации в комплексном лечении пациентов с перинатальной гипоксически-ишемической энцефалопатией.

Материалы и методы. В ходе исследования на базе «Неврологической клиники доктора Яценко» (г. Киев) было обследовано и комплексно пролечено 45 детей в возрасте от 2 до 12 лет с гипоксически-ишемической энцефалопатией. В группу сравнения, которой проводили базисные лечебно-реабилитационные мероприятия, вошли 15 детей; в основную - 30, которым на фоне базисной терапии дополнительно проводили курс микрополяризации. Транскраниальную микрополяризацию (ТМП) выполняли согласно разработанным индивидуальным схемам лечения в зависимости от локализации патологии. Мозговую гемодинамику детей с ПГИЕ до и после комплексного лечения с применением метода ТМП анализировали с помощью транскраниальной допплерографии сосудов головы. 
Огляди літератури, оригінальні дослідження, погляд на проблему, ювілеї

Результаты. ТМП уменьшала коэффициент асимметрии кровотока по средним мозговым артериям (СМА) на 12,7 \%, тогда как в группе сравнения только на 4,4 \%; по передним мозговым артериям (ПМА) - на 9,5 \%, а в группе сравнения этот показатель составлял 1,1\%. ТМП достоверно уменьшала высокие средние скорости кровотока за цикл (ССК) по базилярной артерии (БА), СМА и ПМА (на 22,0 \%, 17,7 \% и 7,5 \% соответственно); в группе сравнения положительной динамики не отмечено. ТМП достоверно увеличивала низкие ССК по БА, СМА и ПМА (на 28,4 \%, 21,9 \% и 10,4 \% соответственно); статистически достоверное возрастание ССК на 10,1 \% было только по СМА у пациентов группы сравнения.

Выводы. Полученные данные свидетельствуют о том, что комплексная терапия с использованием транскраниальной микрополяризации у пациентов с ПГИЕ улучшает показатели мозговой гемодинамики, а также положительно влияет на клиническое течение заболевания.

КЛЮчЕВЫЕ СЛОВА: микрополяризация; перинатальная гипоксически-ишемическая энцефалопатия транскраниальная допплерография.

\section{INFLUENCE OF TRANSCRANIAL MICROPOLARISATION ON BRAIN HEMODYNAMICS IN PATIENTS WITH PERINATAL HYPOXIC-ISCHEMIC ENCEPHALOPATHY}

@K. V. Yatsenko

\section{O. Bohomolets Institute of Physiology of NAS of Ukraine, Kyiv, Ukraine Neurological Clinic of Dr. Yatsenko, Kyiv, Ukraine}

SUMMARY. Introduction. Perinatal hypoxic-ischemic encephalopathy (HIE) is a major issue of neurology and neonatology. A promising non-invasive tool for modeling the activity of the brain - transcranial direct current stimulation is of particular interest in the treatment of HIE.

The aim of the study was to investigate the possibility of using direct current stimulation in combined treatment of patients with perinatal hypoxic-ischemic encephalopathy.

Material and Methods. 45 children aged 2 to 12 years with hypoxic-ischemic encephalopathy were examined and treated at the "Neurological Clinic of Dr. Yatsenko" (Kyiv). The comparison group was formed from 15 children who received the course of basic medical and rehabilitation procedures. The main group included 30 children who, in addition to the same therapy, received a course of transcranial direct current stimulation (TDCS). TDCS was performed according to the individual treatment regimens. A transcranial Doppler ultrasound examination of head blood vessels was used for the study of cerebral hemodynamics in children with HIE before and after combined treatment with TDCS.

Results. TDCS reduced asymmetry coefficient of blood flow velocity in the middle cerebral arteries (MCA) by $12.7 \%$, whereas in the comparison group only by $4.4 \%$; in the anterior cerebral arteries (ACA) - by $9.5 \%$, while in the comparison group $-1.1 \%$. TDCS significantly reduced the high mean blood flow velocity per cycle (MFV) in the basilar artery (BA), MCA and ACA (by $22.0 \%, 17.7 \%$ and $7.5 \%$ respectively); in the comparison group no statistically significant positive dynamics was observed. TDCS significantly increased the low MVF in the BA, MCA and ACA (by $28.4 \%, 21.9 \%$ and $10.4 \%$ respectively); a statistically significant increase of MVF by $10.1 \%$ was only in the CMA in the comparison group of patients.

Conclusions. The obtained results showed that combined therapy with transcranial direct current stimulation improved the cerebral hemodynamics parameters in patients with HIE and also positively influenced the clinical course of the disease. Doppler.

KEY WORDS: transcranial direct current stimulation; perinatal hypoxic-ischemic encephalopathy; transcranial 